\title{
The Question of Female Embodiment and Sexual Agency in Anuradha Sharma Pujari's Kanchan
}

\author{
Koyel Chanda \\ Research scholar, Dept. of English, Pondicherry University. ORCID: oooo-ooo2-9375-2572. \\ Email: chandakoyel@gmail.com
}

\begin{abstract}
The association of women with body has generated a host of negative connotations that have been used to justify their limited political and social role. So, questions regarding the female body and sexual agency are of utmost importance in feminist theories. Anuradha Sharma Pujari, an Assamese author has explored the complex question of female sexual agency in her novel Kanchan. The novel narrates the upheavals caused in the life of its economically and educationally disadvantaged eponymous character when she decides to use her body to make a living for herself and her family. The focus of the paper will be to understand the concept of women embodiment and the complexities surrounding female sexual agency with the help of embodiment theories most notably those forwarded by Meenakshi Thapan.
\end{abstract}

Keywords: women, embodiment, sexual agency, body, feminism

The body holds a special place of inquiry in feminist discourses. The rise of second wave of feminism was marked by a vast body of knowledge dealing with the constructions and complexities of the female corporeality to counter the problematics of biological determinism. Second wave feminist writers like Germaine Greer, Kate Millett, Shulamith Firestone furthered the claims made by early feminists and developed an expansive body of knowledge that was political in nature. Although they conceded that women's association with the body created obstacles to their liberation, they refused to comply with the negative connotations of the body and relied on a woman-centered theory of sexual difference. French Feminists and Anglophone radical feminists read women's embodiment as a source of feminine experience and desire. Radical feminists theorized that women's embodiment gave them access to a superior kind of knowledge and ethical capacities because of their maternal and nurturing roles. Recent feminist studies such as Elizabeth Grosz, Iris Marion Young, Susan Bordo etc have delved deeper into the questions of female corporeality to better understand and address unique female experiences such as menstruation, menopause, pregnancy, childbirth, the development of breasts and questions about female sexuality. These theories have utilized the theoretical frameworks of noteworthy philosophers such as Merleu Ponty, Foucault, Spinoza etc to examine how female embodiment is constructed and regulated by political, cultural and social forces.

Addressing questions of female embodiment has always been an ongoing feminist project. Judith Butler (1988), in the chapter titled "Performative Acts and Gender Constitution: An Essay in Phenomenology and Embodiment" writes about how feminist discourses have always been critical and suspicious of ideas regarding sexuality and embodiment that are grounded on naturalistic views. Distinguishing between sex and gender became a task of utmost importance in feminist discourses to challenge the idea that the uniqueness of female embodiment justified their restrictive social and political roles. She cites Simone De Beauvoir's famous claim that woman is a historical

(C) AesthetixMS 2020. This Open Access article is published under a Creative Commons Attribution Non-Commercial 4.0 International License (http://creativecommons.org/licenses/by-nc/4.0/), which permits non-commercial re-use, distribution, and reproduction in any medium, provided the original work is properly cited. For citation use the DOI. For commercial re-use, please contact editor@rupkatha.com. 
construct / formation in order to stress how the concept of femininity is a dynamic, culture specific process that can be reversed and redesigned. She states:

When Beauvoir claims that "woman" is a historical idea and not a natural fact, she clearly underscores the distinction between sex, as biological facticity, and gender, as the cultural interpretation or signification of that facticity. To be female is, according to that distinction, a facticity which has no meaning, but to be a woman is to have become a woman, to compel the body to conform to an historical idea of "woman," to induce the body to become a cultural sign, to materialize oneself in obedience to an historically delimited possibility, and to do this as a sustained and repeated corporeal project. (Butler, 1988, p. 522)

The process of turning the body into a cultural sign holds especially true in the case of women who have been turned into symbols of purity, fertility, sacrifice, family and social honor and have been denied the autonomy to define themselves. The implications of these kinds of cultural constructions often prove disastrous for a woman's sexual autonomy which is amply embodied in Anuradha Sharma Pujari's Kanchan, an Assamese novel published in 2001. The novel recounts the life experiences of Kanchan, who is born and raised in poverty. She understands that her beauty and her body is the only leverage she had to survive and support her family and thus uses her body as a tool to fend for herself and her family. This familiar fiction of a fallen woman ends with Kanchan's eventual rape and mental breakdown. But what emerges from the narrative is the complex question of women's embodiment and her sexual agency in India where the female body, as already stated, is often viewed as the repository of honour, purity and familial respectability. This paper aims to analyse the novel to understand the unique ideas and constructions of woman's embodiment in India and how a woman negotiates with her socio-cultural environment through her corporeality. Since the novel is in Assamese, I will attempt to translate the relevant passages as textual references for this paper.

Anuradha Sharma Pujari, a renowned Assamese journalist and author is best known for her 1998 novel Hridoy Ek Bigyapon (The Heart's a Showbiz) which garnered attention for its accurate portrayal of modern Assamese life. A prolific writer, she has written numerous other novels such as Mereng (2010), Nil Prajapati (Blue Butterflies) (2013) and Jalachabi published in 2014. Her oeuvre also includes short story collections such as Boxontor Gaan (Spring-song) (1999), No Man's Land as well as a collection of essays named American Charaikhanat Sanbad Basanta aru Bandhu and other editorial and non-fictional writings.

Since the paper focuses on the question of female embodiment, any discussion of the same should follow from a definition of the term embodiment. In the book chapter entitled "Sexuality and Embodiment", Deborah L. Tolman, Christin P. Bowman, and Breanne Fahs (2014) discuss the emergence of a diverse attention to the body in the fields of sociology, cultural studies, literature, psychology etc and how embodiment studies have provided a socio-cultural analysis to the questions of body and sexuality. Embodiment studies locate and provide insight into how bodies and sexualities are not simply natural but can be understood within prevailing structures of power (p. 759). In the same chapter, Tolman, Bowman and Fahs (2014) also provide a definition of embodiment. Embodiment, according to them -

refers to the experience of living in, perceiving, and experiencing the world from the very specific location of our bodies.... Conversely, embodiment can refer to the ways our social and historical environments enter into and become entangled with our bodies. This social constructionist viewpoint emphasizes the mechanisms by which our bodies come to behave 
in certain normative fashions; in short, by living day to day in a society that makes certain demands on our bodies and psyches, we come to internalize these norms or discourses and embody them (e.g., see Bartky, 1990; Foucault, 1978). These norms and discourses form and inform our bodily feelings, behaviors, and comportment, and they constitute the phenomenology of embodiment. (Tolman, et al., 2014, p. 761-762)

In the context of India, female embodiment becomes all the more complex as the gender duality practiced in the west and critiqued by western feminists becomes inapplicable. Studying female embodiment in India cannot be done merely on gender aspirations and constructions. The female body is viewed and regarded differently based on caste, class, location and privileges. Radha Chakraborty (2007), in the Introduction to Bodymaps: Stories by South Asian Women comments on how disciplinary tactics imposed on the female body is based on the differences between the male and female body.

Because the female body, perceived as penetrable, changeable and subject to cyclical rhythms, threatens to disrupt the ideals of order and containment, it attracts the disciplinary, regulative gaze of social power systems....The embodied woman is thus internally divided, for her own experience of her body often contradicts regulatory societal constructions of it. This leads to a sense of fragmentation and lack of control over one's own bodily changes. (Chakraborty, 2007, p. xix)

The female body holds an ambivalent position in a culturally and linguistically diverse country like India. The celebration of female deities on the one hand and the extreme violation of sexual, political and economic rights on the other hand show that the symbolic value attached to a woman has a priority over her real one.

Theories of embodiment have attempted to address the regulatory measures imposed on the body, its disciplined manifestations, resistance, negotiation and transgressions and how the body is always in the process of acquiring new signification. In Living the Body: Embodiment, Womanhood and Identity in Contemporary India, Meenakshi Thapan (2009) stresses on the importance of embodiment in understanding women and their position in India. She argues that a woman is as much located in the physical and psychological space as she is in the cultural and social domain. However such an assessment runs the risk of 'essentialising' women as it might play into the arguments of biological determinism. The alternative to such a misstep, according to Thapan (2009) is to view embodiment in a "social and 'relational' context". She further states in her book:

Woman's personal and social worlds are defined very clearly in terms of the home, the family, their childhood, the workplace and their life experiences through various periods of their lives. In the process of articulating their life worlds, women traverse untrodden paths of revelation, strength and surprise as well as the more frequented ones of abuse, dishonour, shame and rejection. In traversing these paths, women revert to memory, narrative and voice as tools for reconstructing their emotions, thoughts and experiences in making sense of their own constitution as embodied, gendered beings. (Thapan, 2009, p. 5)

Kanchan foregrounds the experiences and struggles of its marginalised protagonist who attempts to circumvent her destitute situation by using her body. Born into poverty to a father who barely made a living as a farmer she makes the only choice available to her. After losing her father, the sole breadwinner of the family and one of her two brothers to malaria, it falls upon her to fend for 
her family. The family's utter poverty could be seen in the fact that the father would occasionally work as a carpenter in order to supplement his income. But the events that transpire immediately after the death of the father provide a clearer indication of their poverty. Kanchan, along with her mother and one surviving brother drag the dead body of the father out of the house into the street so that their house would not be destroyed the following morning since it was a custom of the village that if someone dies in a house, that house must be destroyed. It was also after the death of the father that Noni, a family friend comes to help the family by helping Kanchan get a temporary job in a company but only in exchange for her sleeping with him. Under the circumstances Kanchan does not resist the advances of Noni. She continues to sleep with him to secure a better living condition for herself and her family. With this she voluntarily enters into sexual relationships with men who can further her career prospects. This act can be substantiated in the words of Meenakshi Thapan:

It is not out of place to emphasise woman's use of the body, including her sexuality, as a weapon-for survival, whether to combat the harsh conditions imposed by poverty, to attack the oppressor physically, or to strategically manipulate, coerce or extract the maximum to her advantage. Women seek to maximise their gains through embodied strategies of negotiation and manipulation, contestation and submission, creating desire and suggesting fulfilment. Such sexual strategies are not unknown in the literature about women's sexuality but I contend these embodied acts are as much political acts as they are sexual ploys, seeking to exploit and dominate as much as to sometimes submit to prevailing definitions about Indian womanhood. (Thapan, 2009, p. 9)

Kanchan's sexual transgressions can be viewed as sexual agency in a more gender equal society. However, the unequal power structures of Kanchan's society sees these transgression less as an act of survival and more as signs of unchecked sexuality which can disrupt existing social structures. Kanchan's sexual liaisons have nothing to do with affections and attachments; rather they are just the means to sustain her family and herself in a social set up where she is economically and educationally disadvantaged. However, these transgressions are interpreted as utilizing one's sexuality in a society which has a long-standing tradition of controlling and disciplining of female sexuality for procreative purposes. Hence, Kanchan is ostracized as she is seen as someone who had bartered her sexuality in exchange for familial and professional stability.

Kanchan's sexual encounters are all told in a matter of fact manner to the newly joined engineer Akashjyoti Phukan who had started showing interest in her. Kanchan justifies her decision by first narrating how she grew up in acute poverty and that in the face of starvation sleeping with someone to secure a job did not seem like a tough decision. Kanchan's use of her sexuality can be examined in a social and relational context, rather than as an individual choice. The burden of family responsibility played a decisive role in Kanchan's use of her sexuality. In Living the Body: Embodiment, Womanhood and Identity in Contemporary India, Thapan (2009) analyses the role of body in resisting unequal power relations in the society:

A woman's embodiment is rarely experienced for pleasure or joy; the body is an instrument for survival. In this sense, the body becomes the weapon with which there is a desperate attempt to contest the harsh realities of everyday life in the fight for survival in a world that is ordered by relations of gender inequality and economic necessity. (Thapan, 2009, p. 133) 
Kanchan rarely expresses any dismay or guilt over her decision to utilize her sexuality in order to survive. Tagged as a loose woman by her colleagues, she understands the consequences of her transgressions and maintains a distance with everybody in her office. However, she equally blames the men who had taken advantage of her. According to the eponymous protagonist of the novel:

If the men who come to me can still retain their position as a good husband, responsible father, why cannot I command the same respect? If the society does not allow me to have that power, I will forcefully take it. I know the gossips about me in the office. They too want me to sleep with them; some of them have already given me such indications. ...But I am not a petty whore. I believe I am not a whore at all. If I am a whore, so are the men who come to me secretly. (My translation, Pujari, 53)

The only people who treat Kanchan with respect and understanding are her mother and the office peon Badar. The head clerk in the office Biswanath Das makes no attempts to hide his contempt for Kanchan and frequently writes letters of complaint against her, hoping it would result in her getting sacked. The novel begins with Kanchan being called to Akashjyoti's office after one such complaint. Akashjyoti is made aware of Kanchan's past through office gossips yet he treats her like any other employee and asks her to take her work seriously. Kanchan is taken aback by Akashjyoti's professionalism as she had expected him to come to her with a lewd offer. Slowly a relationship starts developing between the two. Kanchan, however, exercises restraint in committing to him as she sees herself unworthy of marriage and love. Akashjyoti convinces her that he sees her like any other woman and is not bothered by her past sexual conduct. The romantic relationship that Kanchan gradually becomes invested in also has its pitfalls. Akashjyoti's motives in trying to get intimate with Kanchan are not purely romantic in nature. An amateur novelist, who got his previous work published he is in search of an inspiration for his next novel. Kanchan's sexual misconduct provides him with just such an inspiration and he tries to know more about her. Another reason he becomes interested in her is because of the fetish he develops for her legs. On one of his visits to Kanchan's house, he comes across a photo album where a particular photo of Kanchan dressed in a skimpy outfit catches his attention. The image of Kanchan's bare legs creates a long lasting impression on him. Kanchan's sexual agency and misconduct are not taken solely as a mode of survival. Rather they become titillating subjects for a possible bestseller, a male fantasy about loose women and their eventual doom. Female sexuality again becomes a site of male control and domination. The photograph that becomes a constant source of fantasy for Akashjyoti contains within it the story of another male fantasy. The photograph had been taken when Kanchan was barely eighteen years old and was sleeping with a senior officer, twice her age to cement her position as a permanent employee. The photograph which exists as a symbol of helplessness is precisely what arouses Akashjyoti's interest in Kanchan.

Kanchan slowly gets drawn to the possibility of a life partner and a life without compromising decisions with Akashjyoti. A transformation comes about her and it is noticed by others who predict the eventual doom of this relationship. However, Kanchan remains oblivious to all these and starts planning her life with Akashjyoti. A new governmental project takes Akashjyoti away from the office which eventually lands him in some bureaucratic difficulties. Unable to resolve the situation he enlists Kanchan's help and requests her to show the officers of the inquiry commission around. Kanchan reluctantly agrees and spends all her time by the officers' side. As soon as she finishes this task, Akashjyoti requests her to accompany him to a party that is organized for the officials. Kanchan who has by then fallen sick reluctantly agrees to it. After she attends the party she realizes that she is the only woman present there. She wakes up next morning in one of the bedrooms with no memory of how she passed out. She eventually learns that she has been 
gangraped and Akashjyoti had deserted her there. Kanchan finally loses her mind and becomes bedridden. The office staff including Biswanath Das comes to her aid by arranging medical help for her and helping her keep her job. Kanchan never recovers from this trauma though she has no recollection of the events that led to it. She starts exhibiting infantile behavioral tendencies even as she continues working in the office. One of the incidents that exemplify her obliviousness towards social manners is narrated towards the end of the novel:

Kanchan still goes to the office regularly. She doesn't speak to anybody. One day she did a strange thing. She took off her rain-drenched sari and laid it out to dry on the office verandah. Clad in a petticoat and a blouse she sat down at her desk writing something with intense concentration. (Pujari, 2011, p. 116)

The novel ends with Kanchan still living in her private fantasy world which constitutes of a relatively carefree life away from the exploitations and deprivations of her adult life. The novel can be read as another piece of fiction dealing with the consequences of defying societal norms and sexual regulations. Kanchan's pathetic end proves that a woman has little to no sexual autonomy. The concept of sexual agency can very well backfire in a society which benefits from controlling women's sexual and reproductive capacities. Kanchan's use of her body can be read as a form of resistance against a society sustained by unequal social and sexual roles. The concept of resistance is again problematic as it does not always change existing social structures. Meenakshi Thapan (2009) addresses this complexity of resistance in Living the Body: Embodiment, Womanhood and Identity in Contemporary India.

Resistance in fact is a double-edged sword in women's lives, one with which they constantly articulate and exhibit their struggle but one which does not always enable complete success. Resistance, nonetheless, remains central to their lives whether or not it achieves social transformation. (Thapan, 2009, p. xv)

Although Kanchan's resistance provides a temporary period of economic stability for herself and her family it nevertheless ends with her turned into a sexual pawn. Thus, her resistance brings neither a permanent change in the social status of Kanchan nor does it bring about the transformation within society as regards the sexual autonomy of women.

This familiar trope of a woman unabashedly using her sexuality has been used multiple times in literature. Notable examples are Ismat Chugtai's Masooma and Salma's The Hour Past Midnight. However, one common thread running through these texts is the downfall or the punishment meted out to the character who dare utilize her sexuality. In Chugtai's Masooma (2018), for example, Masooma is first forced into selling her body by her mother to meet the needs of the family. Later she willingly enters into sexual relationships with rich men for better living conditions. At the end, she is left penniless in a hotel room with no recollection of what happened to her. In The Hour Past Midnight (2016), Firdaus who belongs to a conservative Tamil Muslim community is married to a rich man against her will. On her wedding night she takes one look at his face and decides to walk out of the marriage. Bearing the tag of a whore, she spends her days being housebound until she starts an affair with a neighbor who happens to be married Hindu man. When her mother comes to know about the affair, she gives poison to her own daughter. Masooma, Firdaus, Kanchan's inevitable tragic ends attest to the fact that even literary creativity is laced with social conditioning that demands that the characters be adequately punished at the end. To conclude, sexuality continues to remain a guilt-ridden aspect of a fictional woman's life and is rarely legitimized or sanctioned outside the structures of compulsory heterosexuality. 


\section{References}

Butler, J. (1988). Performative Acts and Gender Constitution: An Essay in Phenomenology and Feminist Theory. Theatre Journal, 40(4), 519-531. Retrieved from https://www.jstor.org/stable/3207893

Chakraborty, Radha. (2007). "Bodymaps: An Introduction”. In Radha Chakraborty (Ed.), Bodymaps: Stories by South Asian Women (pp. xi-xxx). New Delhi: Zuban.

Chugtai, Ismat. (2018). Masooma (Tahira Naqvi Trans.). New Delhi: Speaking Tiger Publishing Pvt Ltd \& Women Unlimited. (Original work published 1961)

Pujari, Anuradha Sharma. (2008). Kanchan. Assam: Banalata.

Salma. (2016). The Hour Past Midnight. New Delhi: Zuban.

Thapan, Meenakshi. (2009). Living the Body: Embodiment, Womanhood and Identity in Contemporary India. New Delhi: SAGE Publications India Pvt Ltd.

Tolman, D. L., C. P Bowman \& B. Fahs. (2014). “Sexuality and Embodiment.” In D. L. Tolman, L. M.

Diamond, J. A. Bauermeister, W. H. George, J. G. Pfaus, \& L. M. Ward (Eds.), APA Handbook of Sexuality and Psychology, Vol. 1. Person-Based Approaches. Washington, DC: American Psychological Association. Retrieved from https://christinbowman.files.wordpress.com/2011/o7/tolman-bowmanfahs-2014.pdf 